\title{
A COMPARATIVE STUDY ON POVERTY ALLEVIATION BETWEEN MOSLEM AND NON-MOSLEM POPULATED COUNTRIES
}

\begin{abstract}
Ahmad Hudaifah ${ }^{1}$, Shochrul Rohmatul Ajija ${ }^{2}$
Abstract. A Comparative Study on Poverty Alleviation between Moslem and Non Moslem Populated Countries. The paper attempts to explore the problems and roots of poverty, the poverty alleviation progress, programs and policies between selected Moslem populated-countries in Asia and selected nonMoslem populated-countries in Latin America. Three important aspects are concluded. Firstly, the poor are mostly living in rural areas and suburban slums. Second, poverty alleviation efforts in both particular groups of countries have resulted in a better outcome. Other economic indicators such as GNI per capita and income inequality graphic have shown better patterns. Third, there have been different strategic policies and programs implemented between the two groups of countries. Islamic economic notions such as zakah, infaq, and sadaqah play a very significant role in Moslem populated countries, on the other hand, non Moslem populated countries tend to create more radical and creative strategies such as agendas of land reform and tourism industry development.
\end{abstract}

Keywords: poverty, literature survey, comparative study, moslem countries, nonmoslem countries

\begin{abstract}
Abstrak. Studi Banding dalam Pengentasan Kemiskinan antara Negara yang Berpenduduk Muslim dengan Negara yang Tidak Berpenduduk Muslim. Artikel ini berusaha untuk mengungkap akar masalah dari kemiskinan, hasil dari usaha pengendalian kemiskinan, program dan kebijakan negara berpenduduk Muslim terpilih di Asia dan Negara yang tidak berpenduduk Muslim terpilih di America Latin. Tiga kesimpulan diperoleh penulis. Pertama, penduduk miskin sebagian besar tinggal di pedesaan dan daerah kumuh pinggir kota. Kedua, usaha pemberantasan kemiskinan dalam dua kelompok negara tertentu telah menunjukkan hasil. Indikator ekonomi lainnya seperti PNB per kapita dan grafis dari ketimpagan pendapatan telah menunjukan kemajuan. Ketiga, ada beberapa kebijakan dan program berbeda yang dilakukan oleh dua kelompok dari negara terpilih. Ajaran ekonomi Islam seperti zakat, infaq, dan sedekah sangat berperan dalam negara yang berpenduduk Muslim, di samping itu, negara yang tidak berpenduduk Muslim membuat strategi lebih mendasar dan kreatif seperti rencana pembangunan dan industri pariwisata.
\end{abstract}

Kata kunci: kemiskinan, survei kepustakaan, studi banding, negara muslim, negara non-muslim

\footnotetext{
Received: June 30, 2016; Revised: November 21, 2016; Accepted: November 30, 2016

${ }^{1}$ Universitas Semen Indonesia, Jl. Veteran, Sidokumpul, Gresik, East Java

${ }^{2}$ Airlangga University Indonesia, Jl. Airlangga No. 4-6, Gubeng, Airlangga, Surabaya, East Java

E-mail: ' 1 ahmad.hudaifah@uisi.ac.id; ${ }^{2}$ shochrul.rohma@gmail.com

DOI: 10.15408/aiq.v9i1.3222
} 


\section{Introduction}

Combating poverty and improving the well being of mankind has been one of the most challenging economic development agendas of the $21^{\text {st }}$ century (Adnan \& Ajija, 2015). Rampant poverty, famine, illiteracy and social problems are among the global issues emerging into the picture of today's economy. Meanwhile, several countries grouped as the developed countries around the world have declared their economic achievements as the most leading economy. Ironically, when many countries are competing to double their GDP per capita as one of the prominent economic indicators, in contrast the remaining world population is still living under the poverty line whereby they have to survive with 2,00 USD per day (World Bank, 1993; Todaro \& Smith, 2006; and Whitman, 2008).

An uncountable number of policies and incentives have been addressed to alleviate and reduce poverty, so far it has been difficult to solve due to several surrounding problems. Every county has its own poverty problem and each country comes up with different solutions with respect to their unique poverty criteria and root issues. Thus, it is very interesting to study the way forward every country undertakes along with the poverty alleviation strategy and policy being undertaken (Wratten, 1995).

This paper aims to provide a comparative study on poverty alleviation in several countries, especially those who have problems with rampant poverty and undertook successful methods of alleviating it. By classifying those counties into two groups, which are Moslem populated-countries and western countries, the paper is expected to be able to analyze very specific distinctions and policies. Features of poverty alleviation program between Moslem populated countries and western countries have varied according to local potency and resource, poverty problems, and cultural condition (Otsuka \& Hayami, 1988). The Moslem populated countries are represented by Indonesia, Malaysia and Bangladesh; on the other hand, Venezuela, Brazil and Bolivia are countries in the western society depicting successful poverty reduction program. Such countries are considered to be able to halve poverty gradually. In addition, six countries are selected because of unique policy approach and society participation.

The study about poverty has been receiving plenty attention from worldwide as the key fundamental topics benefiting policy recommendation. In the area of distinctive aspects the majority of study focuses on geography and country case. The poverty reduction and alleviation are very fertile area of research examined from different perspective and objective. The comprehensive study aims to identify and develop poverty alleviation program compatible with local wisdom, religious based, and culture, is definitely needed. The comparative 
poverty study considers the society belief of a country between Moslem-populated and western. The paper attempts to deliberate comparative issues from several points of view such as poverty condition between two characteristics, society participation, government priority program, and the presence of micro-credit and microfinance.

The organizational structure of the paper consists of three chapters of discussion. First, it begins with introductory parts, deliberating background of the study, which explains why the paper is written and what the motivation triggers. Second, it continues to the literature review, dealing with the connection between the present study and the previous researches done on related matters. Third, methodology is explained, by describing how the paper is produced and formulated. Fourth, analysis and discussion is primarily the main concern of the present paper, in which the findings of the study are being conducted. Last but not least, the conclusion, whereby it summarizes prior chapters into a cogent and brief paragraph.

\section{Literature Review}

The call of the Millenium Development Goals (MDGs) to end poverty by 2015 has become one of the main themes in today's economic development agendas worldwide. It was the year 2000 historical milestone in human civilization when leaders from around the world met and agreed to declare poverty as a common enemy and addressed eight agendas that have prioritized alleviating poverty as the first target. The collective efforts and the made-promises to remain on the track of the poverty alleviation agenda across nations and regions are still being tested as of today. Many of the development targets such as free trade and economic growth orientation have already taken place. Their endeavor is to hold firmly to alleviating poverty as the main agenda toward 2015 MDGs. Extreme poverty is likely closer to extreme hunger because people without sufficient income cannot afford their basic needs. Extreme hunger and famine lead to the chaotic catastrophes of modern mankind. Currently, it is believed that 920 million people are living under the international poverty line, which means they survive on 1.25 USD per day (UNDP, 2002). Mostly, they are living in developing country regions like Southern Africa (51\% of total population), Southern Asia (39\% of total population) and Latin America \& Caribbean ( $8 \%$ of total population). It has been the target of the MDGs 2015 is to halve, between 1990 and 2015, the proportion of people whose income is less than $\$ 1$ a day. The strategy to alleviate extreme hunger is two sides of an integrated-program together with poverty, by creating job opportunities in the long term and food aid in the short term, ultimately all people living under the 
poverty line can find the jobs or full and productive employment and decent work for all. Thus, food and basic needs are affordable for all people living in developing countries.

The program of the MDGs toward 2015 should be appreciated by all elements of the global community, no matter if they belong to Eastern or Western societies. All major role players have to work under the same platform: (1) Eradicating extreme poverty, (2) Achieving universal primary education, (3) Promoting gender equality and empower women, (4) Reducing child mortality, (5) Improving maternal health, (6) Combating HIV, Malaria \& other diseases, (7) Ensuring environmental sustainability (UNDP, 2002).

\section{Methods}

The methodology employed is qualitative analysis by conducting literature survey, report analysis and data mapping. All sources referred will be secondary data issued by reliable institutions. Once data, articles-journals and official reports are completely collected, the analysis begins with mapping and analyzing the poverty problems, then proceed to strategies used by each country and ends up with solutions undertaken by each country.

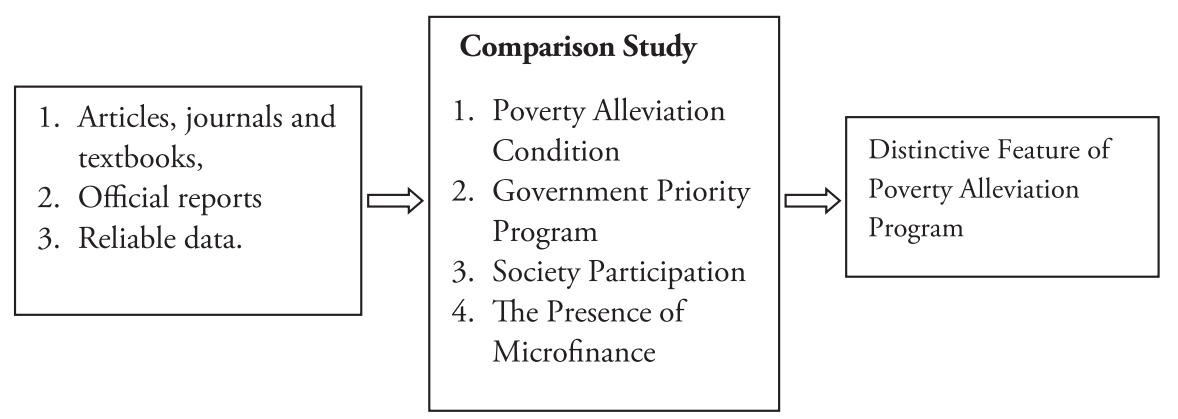

Figure 1. Comparative Study Flow

Technically, departing from the rarity of studies, particularly in comparative analysis of developing countries between Moslem populated countries and non Moslem populated countries, this article will focus on three major relatedliterature reviews in the area of poverty alleviation, which are (1) articles, journals and textbooks, (2) official reports and (3) reliable data. The periods of study are also restricted starting from 1990 until 2015. The countries taken as models are also specified into two main regions: Latin America and Asia. Later on, Latin America (Brazil, Bolivia and Venezuela) represents Western countries and in 
contrast Asia (Bangladesh, Indonesia and Malaysia) represent Moslem populatedcountries.

The process of data collection involves online searching and direct visiting to IIUM library to find relevant textbooks. This study has collected 23 relevant journals and articles, written by scholars, policy makers and economists in both groups of countries and downloaded from reliable providers. From World Bank websites, the statistical data on poverty indicators such as the number of poor people, earning 2 USD daily income, GNI per capita and inequality of income have been adopted and extracted (Chyper \& Dietz, 2009). From library resources, this paper has utilized textbooks and official reports in the areas of economic developments, poverty alleviation studies, study of development process and handbook of poverty alleviation around the world.

After all information, sources, reports, articles-journals and statistical data were gathered and collected, classification and mapping were the next steps. All data classified into two categories: Moslem populated countries in Asia and Non Moslem populated countries in Latin America. Then, all are studied, examined and reformulated before writing the entire paper.

\begin{tabular}{|c|c|c|}
\hline $\begin{array}{l}\text { Islamic Countries } \\
\text { Indonesia: The Largest-Moslem } \\
\text { Population around } 220 \text { Million with } \\
\text { income per capita } 3843 \text { USD/2015 } \\
\text { Malaysia: One of the Modern } \\
\text { Islamic Countries with income per } \\
\text { capita } 10876 \text { USD/2015 } \\
\text { Bangladesh: The Success Story of } \\
\text { Microfinance in Islamic countries } \\
\text { with income per capita } 972 \\
\text { USD/2015. Country with extreme } \\
\text { poverty case }\end{array}$ & 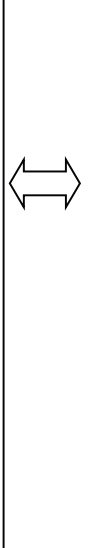 & $\begin{array}{l}\text { Western Countries } \\
\text { Brazil: One of largest economy in } \\
\text { developing countries and its } \\
\text { population is almost equal Indonesia } \\
\text { with income per capita } 11159 \\
\text { USD/2015 } \\
\text { Venezuela: One of developing } \\
\text { countries promoting land reform for } \\
\text { the poor with income per capita } \\
12793 \text { USD/2015 } \\
\text { Bolivia: One of developing country } \\
\text { with income per capita } 2372 \\
\text { USD/2015. Country with tremendous } \\
\text { inequality in term of wealth }\end{array}$ \\
\hline
\end{tabular}

Figure 2. Sample Country Reason

\section{Result and Discussion}

Based on statistical results of the poverty indicator issued by World Bank, the data briefly demonstrates the declining trend of the number of poor people in the selected countries below. The statistical data remains the number unless it is interpreted properly. And the reliability and validity of the data are still questionable 
for the public, whether it is the result of policy and strategy, or manipulation and politic propositions. Regardless, of the debatable of the data, the only source found officially reveals the fact aforementioned, that for 2 decades fighting poverty in developing countries, here classified into Moslem-populated countries and Western countries, indicate positive outcome. Except, several countries like Bangladesh depict worse indicators, where the number of poor people increased slowly.

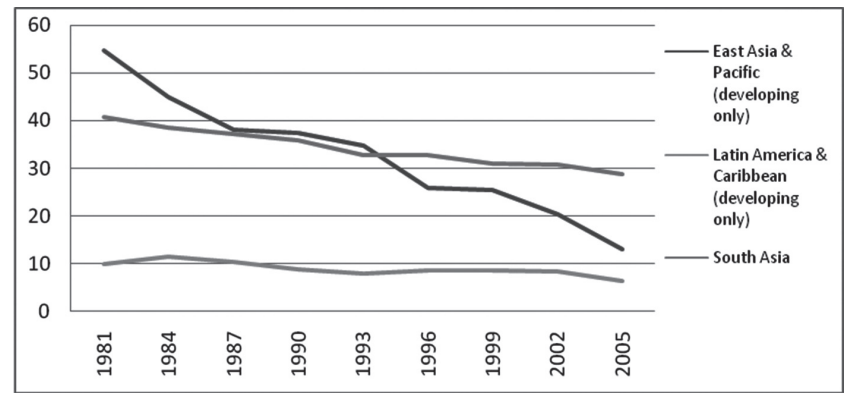

Source: World Bank (2011)

Figure 3. The Poverty Trend in the Selected-Developing Countries by Regions

(2 USD \$ Per-Day Standard)

The three selected-Moslem populated-countries, which are Bangladesh, Indonesia and Malaysia, are striving to eradicate extreme poverty. Through statistical data output, it shows that Malaysia is the most successful country among selected Moslem countries in eradicating poverty remarkably from $9.64 \%$ in 1984 to 2.03 $\%$ in 2008, with respect to total population. Indonesia as the biggest Moslem country in the world is still facing problems in addressing poverty programs because of density of population dominated by poor people in sub-urban and rural areas, but its achievements are incomparable to the other nations. By 2009 Indonesia was able to halve the number of poor people, from $42.83 \%$ of total population in 1984 to just $15.43 \%$. Of course it has not been an easy task to alleviate poverty with the challenges of geographical locations and cultural conditions. Bangladesh is running behind the other countries because of several problems and limitations determined by a lot of policy implications and prescriptions (Dorosh, et.al, 2004).

To examine poverty alleviation by looking at the number of poor successfully reduced is not the broader way; rather several indicators must be incorporated such

${ }^{1}$ Poverty gap is the mean shortfall from the poverty line (counting the non poor as having zero shortfall), expressed as a percentage of the poverty line. This measure reflects the depth of poverty as well as its incidence. 
as GNI per capita and inequality, demonstrating the wider picture of the economy (Jones \& Nelson, 1999).

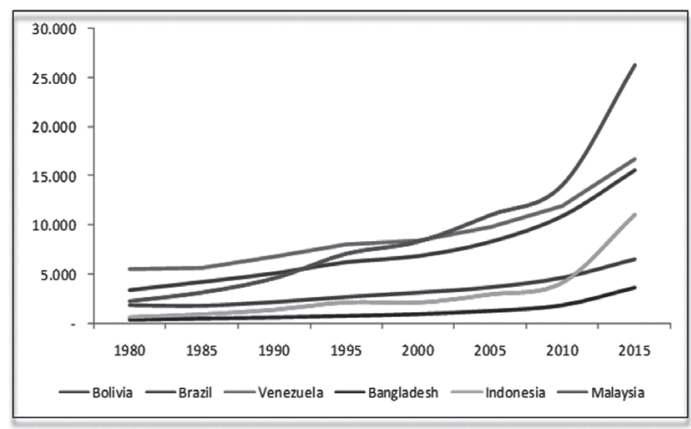

Source: World Bank (2015)

Figure 4. Selected-GNI Per capita on US Dollar purchasing power parity

The data from the World Bank roughly explains the result of policies addressed by respective countries. Basically, Non-Moslem populated countries in Latin America have started the development process with higher GNI per capita, but less unequal income per capita, meaning that the economic resources are not equally distributed. On the other hand, Moslem populated countries in Asia have primarily addressed the economic equality by focusing on income distribution.

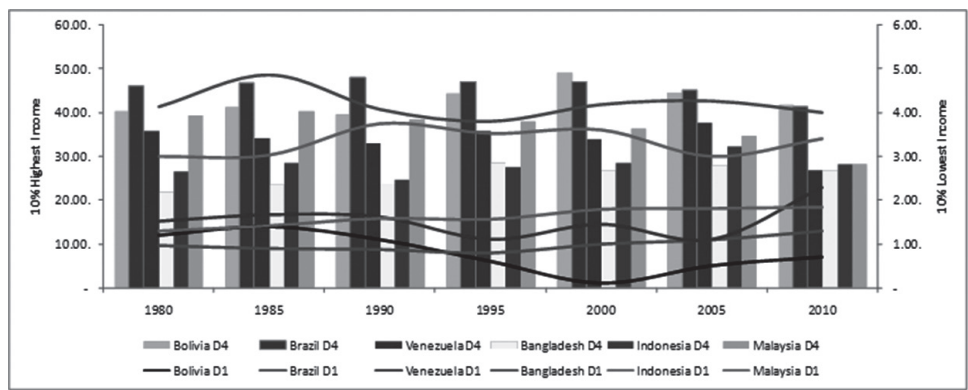

Source: OECD (2016)

Figure 5. Income Comparison between $10 \%$ Highest and $10 \%$ Lowest

According to Figure 4 and Figure 5, it can be asserted that between 1980 and 1990 the Non Moslem populated countries in Latin America have had a better GNI per capita while Moslem populated countries in Asia have had a better equality of income per capita, by looking at the distributional income gap between the income share held by the $10 \%$ highest and $10 \%$ lowest in each country. However, Malaysia 
succed to increase its GNI per capita sharply since 1995 until the end of 2015 and still performed in good equality income distribution. In addition, Indonesia also had tremendeous improvement in its GNI per capita since 2010. Therefore, it will be possible for Moslem populated countries such as Malaysia and Indonesia to reduce their poverty rate and increase their GNP per capita in the future faster.

\section{Poverty Alleviation Condition}

Poverty alleviation is a big agenda for the Indonesian government since declaring its independence in 1945 and as of today this policy has been a primary objective and concern set up by all administrations that have come into office over time. The poverty alleviation strategy and policy for the Indonesian government must address the roots of impoverishment itself such that they are rightly implemented. Eckholm (1979) and Tambunan (1998) reveals that there have been several poverty issues in Indonesia, which are: (1) average low level of income, (2) urban and rural disparities involving the backwardness of rural and suburban slums, (3) women, their poverty and their minimum participation in the development process, (4) income growth, poverty and the wider degree of inequality and (5) low level of human development. In addition, the low level of human development has worsened and discouraged the process of poverty alleviation and thus has been the first priority after general strategy. The origin of why the Indonesia human development index has been very low lies in six main factors, which are (1) deficiencies in planning, (2) system building and financing, (3) capital bias, (4) urban bias, (5) gender bias, (6) civil service organization weaknesses and corruption (Tambunan, 1998).

Malaysia is an IDB member country that has been successful in eradicating poverty by reducing the number of poor people surviving on $2 \mathrm{USD} /$ day from $9.64 \%$ of the total population in 1984 to $2.03 \%$ of the total population in 2008 . Malaysia has continuously been making long-term attempts in improving its level of wealth and prosperity since declaring its independence and the beginning of the poverty alleviation program, which began in 1960 and continued until recently. For the Malaysian government, the primary concern of poverty alleviation is placed in the bigger picture of economic development which has focused on "socioeconomic planning, structural and trade adjustments and adoption of pragmatic policies that promoted agriculture as well as the manufacturing sub-sector to create higher productivities, incomes and standards of living" (Salih \& Colyer, 2000). Since 1970, the new strategy was imposed by planning a new economic policy (NEP) and a new development policy (NDP), which was adopted in 1971 and 1991, respectively, as models to promote more rapid and equitable development. 
After fighting against hardcore poverty, the demographic of people receiving bellow 2 USD in Malaysia still exists, but has been rendered controllable through direct subsidies to the needy. In the case of financial and economic recessions, the number of poor might increase because of scarce job availability. The Malaysian government in 2000 also developed the bottom line of poverty alleviation by empowering the poor through small and micro businesses, whereby the poor were stimulated to be independent, creative and resilient. Unlike the first strategy which was initially implemented from 1960 until 1990, which emphasized on government initiatives. The micro-financing programs initiated also involved the private sector and voluntary organizations. This was designed not only to assist the poor people in running businesses but also to strengthen the economy in general. Those who are especially in need are small and medium enterprises, which are easily affected by the fluctuation of economic conditions, particularly when a recession hits. Therefore, such programs would stabilize the poverty line by assisting small business enterprises to operate regularly despite any economic crises.

Bangladesh, a country with huge environmental and climate change problems as well as hidden-potentials of human resources has been independent since 1971 (McCarthy, et.al, 2001). Bangladesh has a total area of about 145,000 sq $\mathrm{km}$ and the population currently is approximately 125 million. This country suffers from severe floods, cyclones and poverty. Among the inherent problems are its rampant rate of poverty that is one of the worst among all the Moslem countries in specific, and the world in general. The majority of the poor is living in rural areas, which is basically subsistence agriculture with smallholdings and sharecropping (Khan, 1986; Khan, 2000a). Agriculture is the primary source of income and employment, but the labor forces in the rural areas do not have full time or remunerative occupations (Bardhan, 1984). According to Khan (2000b) more than 60 percent of the farmers are landless or have a tiny holding, with the population density being the highest in the world, about 80 percent of the population live in villages and the increase of population per capita in regards to cultivable land is gradually reducing and there is tremendous pressure on land. As a result of difficult economic conditions in rural areas, many workers and farmers move to urban areas and major cities like Dhaka, living as the urban dwellers in sub-urban slums surrounding cities and working in informal sectors with low levels of income (Khan, 2001).

Brazil is among the largest economies in the developing world; nevertheless it performs very badly in terms of social outcomes (Filho \& Vasconcellos, 2004). While Brazil has the highest level of per capita GDP, it also is the most unequal. In terms of macroeconomics, it was one of the fastest growing economies between the 1960s and 1970s, embodied in the well known "miracle period", whereby per-capita GDP at that time jumped from $\mathrm{U} \$ 2,000$ to about $\mathrm{U} \$ 6,000$, thereafter followed 
a stagnation period, and the recovery observed after the successful stabilization through the Real plan in 1994 brought rather disappointing growth rates (Filho \& Vasconcellos, 2004). Lately, GNI per capita in Brazil has reached 10,920 US Dollars in 2010, which is remarkable macroeconomic performance in the developing world. Brazil has much relied on its growth achievement to develop its economy as well as to alleviate poverty. Growth is strongly related to poverty reduction, initially there were 61 million people living under the poverty line in 1970, as compared to 33 million in 1999. According to (Filho \& Vasconcellos, 2004), a comparison between per capita GDP and poverty over the last 30 years clearly exhibits that the two are highly inter-correlated over time, between 1970 and 1980, when Brazil almost doubled its per capita GDP, poverty at the national level fell from $70 \%$ to about 35\%. On the other hand, Brazil suffered a recession between 1980 and 1983 and poverty increased about 5 percentage points, accordingly.

Unfortunately despite its wonderful culture and amazing traditional way of living, this country preserves the very fundamental problems in the millennium era: poverty, low rank of human development index and rampant inequality (Bautista, 1992). Indeed, among Latin America countries, Bolivia is the least developed or among the worst in the region (Sánchez \& Franklin, 1996). Based on the data issued by UNDP (2002) and World Bank (2011), HDI at birth years (per 1000) is 0.648, its life expectancy is 62 years and its illiteracy rate under 5 is up to $83 \%$ and its adult illiteracy rate is better, $15 \%$. From social-poverty indicators, $10.1 \%$ of the total population is still living under the poverty line, whereby the poorest $64 \%$ are mostly indigenous people living in rural areas.

Like some other Latin American countries, in 2007 the inequality rate on income in Bolivia reached an alarming rate. It was severe to the extent that income share of the highest $10 \%$ of the population reached $45.42 \%$ of total income and in contrast the income share of the lowest $10 \%$ of the total population was only $0.99 \%$ of total income (World Bank, 2015). In 1997, the Gini coefficient in Bolivia was 58.9, the worst compared with other Latin American countries, even like Brazil and Argentina. This situation has been worsened by Bolivia's external debt, which has created indebtedness among its citizens and influenced taxation and the social expenditure budget.

Being luckier than Brazil and Bolivia, its economy has benefited from the changing national policy and strategy of moving from agriculture-based economy to a petrol and oil-based economy without abandoning the strategic role of agriculture sector. At the beginning of 1980 and the end of 2004, the poverty in Venezuela was indeed getting worse and worse until reaching $14.64 \%$ of its population, albeit while the government was generating money from the oil and petrol industry. In addition, the inequality ratio was slightly higher at that time, in which until 2003, 
income share held by highest $10 \%$ was still above $35.42 \%$, and income share held by lowest $10 \%$ was below $0.96 \%$. Since Hugo Chavez was elected and took power, the most revolutionary policy at that time until today, was nationalizing oil and petrol companies and putting them under government control. That shift in policy became the turning point, not only for Venezuela's economy but also international relations of staying away from Western multinational corporation interventions. By utilizing the oil and petrol money, the Venezuelan government began to subsidize the poor, as a result from 2000 to 2006 , the number of poor declined to $8.34 \%$, and then it dramatically decreased in 2007 to $2.76 \%$. The gap between the poor and the upper class at that time started to narrow, in 2006 income share held by the highest $10 \%$ became $32.95 \%$, and income share of the lowest $10 \%$ reached 1.85 $\%$. Recently, Venezuela's income per capita reached 11.95 USD in 2010, which is among the middle-income countries in the world.

\section{Government Priority Program}

According to Tambunan (1998) poverty alleviation and empowerment programs in Indonesia have been launched to overcome recent issues. Since 1960 until the new order regime lead by President Suharto ended in 1998, the Indonesian government has focused on several policies. As of today some policies are still relevant and have prevailed, i.e. minimum wages, presidential instructions of the left villages, family welfare programs, agricultural development programs, Integrated Area Development Program (IADP), and transmigration second stage developments (Todaro \& Smith, 2006).

After President Suharto was no longer in the office and passed on his administration to President B.J. Habibie, the reformation order began. Poverty alleviation was still the main concern of the elected-president but with a different form using a similar platform and continuing former programs. Recently, following the emergence of the banking and finance sector development, government programs are being synchronized with the innovative creation of banking products designed for the people who are considered poor or near the poverty line, such as microfinance. These products are embodied in the government institutions, private institutions or joint ventures between the private sector and the government. These programs are making use of the modern banking system, which is able to reach the remote areas and rural regions of Indonesia's territory. Microfinance in the 21 st century for the Indonesian government is being considered as a powerful strategy in alleviating poverty like many other countries in the world. Regardless of the positives or negatives surrounding it, micro financing has begun to be offered by public and private banks in Indonesia with special requirements, terms and conditions addressed for the poor. 
The special rights and privileges were given to Bumiputra or indigenous ethnics in Malaysia to be engaged in the economic development process, because "a large share of the poverty in Malaysia in 1970 was concentrated among the Bumiputra (indigenous Malaysians), who tended to be clustered in rural areas and therefore pursued farming occupations". The Malaysian government has also addressed stimulus and packages of programs under integrated-policies to assist the poor and improve their income per capita. As a result, poverty has declined and the household income has gradually increased. Both of these developments are attributed to a number of factors with rapid and sustained growth being an essential element as well as the active role of the government. Between 1960 and 1995, social development goals such as education, health care and nutrition became primary concerns as well, such that social well-being per capita supported the improvements of income. As of now, the integrated-programs have remarkably taken a place in many sectors of the Malaysian economy. Thus, it has been proven that higher income per capita among Malaysians is gradually achievable and inequality is gradually decreasing.

Bangladesh government has strived to tackle and fight poverty by allocating a social expenditure budget (Hofer \& Messerli, 2006). Spending aggregates are allocated to overcome the social-poverty problem. As a matter of fact, Bangladesh ranks $67^{\text {th }}$ in the human poverty index, 12 th from the bottom among 78 developing countries (Huq, 1998; and Hutton \& Haque, 2004). The Human Development Index ranks Bangladesh $123^{\text {rd }}$ among 146 countries (UNDP, 2002). According to World Bank's new system of measuring the real wealth of nations, Bangladesh's ranking is 12th from the bottom among 192 countries and the wealth endowment of the country is estimated at only 3.6 per cent of the global average with 79 per cent of the country's wealth being attributed to human resources (Ullah \& Routray, 2007). The effort of Bangladesh's government to tackle the social poverty problem more seriously is due to the World Bank's and world community's evaluation.

Despite the rampant poverty remaining 4.26 of income share held by lowest $10 \%$ in 2005 and 1800 USD income per capita in 2010, Bangladesh is one of the most inspiring countries in alleviating poverty, by involving outstanding microcredit institutions like Gramen bank. This successful story has spread out around the world and its concept has been reduplicated and modified in many countries. In reality, the presence of microcredit institutions is not alone, because there have been some non-government organization (NGO) also offering microcredit massively. Historically after the war of liberation in 1971 with the shattered economy caused by the war, other millions were left on the brink of starvation, then the NGOs came forward with the task of relief and rehabilitation, they are legally registered under the Voluntary Social Welfare Agencies, wishing to receive foreign funding. 
Since all foreign donations came in this country for poverty alleviation, more than 20,000NGOs are involved in the development efforts undertaken in Bangladesh focusing on poverty alleviation. Thus, beside the microfinance institution, the NGO involvement in offering microcredit has begun.

Unfortunately, according to Khan (2000b) in spite of a lot of NGOs and micro-financing institutions in Bangladesh the small or marginal farmers are still difficult to access credits, although some NGOs have been providing credit but this hardly reaches the poorest section of the community. Moreover, the cost of credit such as interest rate and administration or service fee even for the poor is high enough, for example usually 20 percent charged for interest and 5 percent charged for service, such that it seems those NGOs providing the credit become richer. Therefore, microfinancing institutions and NGOs not only have brought about the successful story but also created hardship and misery for the rest of poor people in Bangladesh.

The growth strategy to eradicate poverty in Brazil is always selected by policy makers in the best way. By readjusting the policy implementations, growth is the most appropriate for them. Employing data from Brazil's Annual National Household Survey released by Instituto Brasileiro de Geografia e Estatística - IBGE, between 1981 and 2000, Filho \& Vasconcellos ( 2004) evaluated and concluded that that headcount poverty declined substantially over our sample period, from $32 \%$ in 1981 to about $26 \%$ in 2001 , but that most of the decline occurred between 1993 and 1997. However, inequality also increased between 1981 and 1989, but it declined between 1989 and 1997, which is probably due to the fall in inflation rates, then starting from 1998 the inequality indeed became wider and wider. Albeit growth-oriented sectors were performing well, it is widely known that Brazil's growth strategy has led it to becoming the most unequal country in the world (Childress $\&$ Murnoz, 2008). The inequality caused by the growth oriented-strategy has created other social-economic problems, such as regional disparity and inequality, health and education inequality over regions, gender disparity and ethnic discrimination.

Regardless of the wider inequality, it does not mean the Brazilian government does not address and come up with innovative policies for reducing poverty. Two very substantial policies, which are remarkably influencing poverty alleviation programs around the world are: (1) engaging the poor into Brazil's tourism industry and (2) land reform allowing the poor/ landless farmers to own the cultivation and farming fields freely. The first reason why Brazil chose tourism is because they have been afforded abundantly beautiful panorama and scenes with exotic geographical locations offering some of the best destinations for vacations and holidays. In addition, the effect of tourism into Brazil can create more job opportunities and also gradually increase the income of the poor that are working in tourism industry. 
The endless rampant poverty and acute illiteracy rate does not indicate that the Bolivian government is not striving to bring about efficacious policies. In fact, a lot of policies have been formulated and implemented until today. The most common and feasible method chosen is allocating a portion of the national budget to social welfare, educational, healthcare and poverty alleviation programs and subsidies both in the rural and sub urban areas (Quang-Dao, 2004). In 1987 the Bolivian government launched the "Bolivia Emergency Social Fund" (BESF), whereby it covered: (1) service provision in nutrition, health and education, (2) infrastructure creation in nutrition, health, education, housing, urban development, road maintenance, irrigation, reforestation, water and sewage, (3) productive activities such as the capitalization of small rotating credit schemes, (4) institutional support for the requesting agencies and (5) administrative costs of the social funds (World bank, 1993). However, similar to other developing countries, in which corruption and mismanagement have generally remained unsolvable phenomena and even getting worse, the social expenditure in Bolivia is not effectively distributed. A World Bank reports in 1993 revealed, "the very poor have benefited little from public expenditures. They have little or no access to infrastructure or social services such as health care, education and training".

Similar to any other countries in the world, the poverty alleviation program is the most prioritized planning in Venezuela. Benefiting from its oil and petrol pumping as well as its reserves, the Venezuelan government has continuously allocated high expenditures for social sectors. As a result, between 1999 and 2000 Human Development Index (HDI) at birth (per 1000) was 0.769; life expectancy was 73 and illiteracy rate under 5 was $23 \%$ and adult was $8 \%$, in which those indicators were high among Latin American countries. Albeit the government has placed a focus on social expenditure, since 1980 Venezuela has not depended much on external debt compared to the other Latin America countries. Thus, its economic sovereignty against foreign interventions has prevailed and no dictations have come from foreign parties. Thus Venezuela has had the liberty to freely direct its own domestic policies including in selecting and maintaining social expenditure programs. However, like in any other developing countries, the social phenomena has also corrupted the poverty programs, whereby most of them are implemented on general food subsidies, and the middle to higher income families consume nearly $60 \%$ of the subsidized goods (World Bank, 1993). In addition, the problems of racism, discrimination and lack of needed policies have seemed to become greater and greater, especially among the black communities (Afro-America) living in suburban slums. They have remained behind the development process and become the poorest minorities in Venezuela, facing difficulties to access health care, education and job markets. 


\section{Society Participation}

In Indonesia, poverty issues do not only involve government concern but also social concern as well. The Indonesian government has designed a lot of programs both long term and short term to alleviate poverty massively. In addition, government facilitates all citizens to participate by offering poverty programs in order to support and enhance the government's program. For instance in the business sector, the Indonesian government encourages private companies to spend their money in form of corporate social responsibility funds. Moreover, nongovernmental organizations, religious groups and voluntary sectors are engaged in reducing poverty, for example, as a Moslem majority populated-country, the Indonesian government promotes zakah, awqaf and Infaq to be an alternative fiscal tool in alleviating poverty recently. Indeed, the government officially institutionalized and enacted a special body to manage and distribute zakah, Infaq and sadaqah in alleviating poverty such that the government programs are effectively supported (Kholid, et.al, 2009). However, until today the poverty alleviation programs in Indonesia have been dominated by government policies and strategies rather than private and voluntary sectors, at least according to what has been recorded by official reports or academic researches.

Interestingly, the state and central government of Malaysia takes care of zakah, infaq, sadaqah and awqaf management and distribution, and all related matters are regulated under Malaysian legal jurisdictions and laws. Under the Department of Islamic Development Malaysia (JAKIM) is the Baitulmall division that is responsible for coordinating particular activities at the state level. Zakah, infaq, sadaqah and awqaf in Malaysia are managed, by individuals, zakah payments are deductible from actual tax, but there is no such tax rebate for businesses and companies paying zakah (Ahmed, 2004). Moreover, Islamic micro-financing services in Malaysia have developed breakthroughs and flexibilities in contracts and financing choices, which are friendlier to the society and more ethical. For instance according to (Rahman, 2010), the application of qardhul hasan, murabahah, and ijarah schemes are relatively easy to manage and will ensure the capital needs (qardhul hasan), purchase of equipments (murabahah) and leased equipments (ijarah) for potential microentrepreneurs and the poor. In addition, the partnership schemes of mudharabah and musyarakah hold great potential for microfinance purposes as these schemes can meet the risk sharing needs of the micro entrepreneurs.

For the Bangladesh, the most difficult is natural disasters and calamities compared to the other complicated and acute problems like rampant poverty, uncontrollable population growth, environmental degradation, poor agricultural and industrial production, rampant corruption, bureaucratic complexities, inadequate policies, ineffective democracy in the politics (Sapir, et.al, 2004). Almost all program- 
implemented including poverty alleviation and microcredit are gone when natural disaster (massive flood) hit rural areas and farming land entire Bangladesh (Shillabeer, 2008). Ever recorded, Bangladesh has been affected by 282 disasters between 1904 and 2004 with nearly two-thirds having occurred since the 1970s alone.

The land reform policy known as: Brazil Land-Based Poverty Alleviation Project, addresses the poor who do not have adequate access to land in the rural areas, particularly in the Northeast. Since 1995, the Government has legally redistributed land to about 372,500 families, using a combination of the traditional approaches through expropriations, settlement on government-owned lands, and direct negotiation of land sales by the government with landowners (Childress \& Murnoz, 2008). The land reform policy has been very successful in alleviating poverty in Brazil. It is one of many examples in the initial pilot project joint venture with the World Bank. The pilot project operated between 1997 and 2002 and benefited 15,267 families who bought and settled on 398,732 hectares of farming and plantation land, acquired at a per hectare cost of about R $\$ 191$ (US\$183 at appraisal exchange rate, or US\$ 54 at closing), or at about $\mathrm{R} \$ 4,759$ per beneficiary family. Finally, this program could increase the beneficiary nominal incomes by an average $180 \%$ from 1998 to 2003, equivalent to a monthly per-capita income of $\mathrm{R} \$ 122$, significantly above the poverty line of $\mathrm{R} \$ 70$.

\section{The Presence of Microfinance}

The latest microfinance applications and programs in Indonesia are actually combining the existing-practices and the concept of Islamic economics, whereby promoting services free from interest, speculation, gambling and injustice (Sadeq \& Hasan, 1997; Rahman, 2010). By introducing the new sources of funds, such as zakah, infaq, sadaqah purposed for the poor to start new businesses, Islamic microfinance has begun to support government alleviation programs in Indonesia. In 1992 when the Islamic economic system was no longer alien and several Islamic banks were established, the following phases contained the structuring of several Islamic micro-financing products. At the beginning of the year 2000, not only were products developed, but they also outnumbered Islamic micro-financing institutions (rural Islamic financing banks), reaching the rural areas and remote villages that were never served by commercial banks.

Compared to the existing microfinance products and any other applications in the world, rural Islamic financing banks in Indonesia offer two unique features. First, several Islamic micro-financing institutions both public and private have been able to cover financial services deep into the countryside, reaching many of the poor by involving a wide network of local community based participations. Second, the members of non- 
profit organizations and institutions offering such Islamic micro-financing services are dominated by cooperatives and zakah, infaq and sadaqah institutions which have some programs concerned with poverty alleviations (Obaidullah, 2008).

Historically, microfinance was introduced in 1986 by replicating the inspiring Gramen bank's successful story in Bangladesh. Specifically by eliminating long procedural processes and heavy collateral guarantees imposed by the existing banking system, at that time Gramen bank was able to deliver credit to the doorstep of the poor. Since this program was launched, being a part of the poverty alleviation strategy, it has been a very popular approach, particularly in approaching the poor who have been excluded from the formal credit sector. Currently, there are gigantic microfinance institutions that have been established to execute the Malaysian government's visions, namely Amanah Ikhtiar Malaysia (AIM), Yayasan Usaha Maju (YUM) and Koperasi Kredit Rakyat (KKR). Furthermore, each institution has gone forward to introduce several workable and viable microfinance services (Ahmed, 2004). Amanah Ikhtiar Malaysia firstly came up with Ikhtiar Loan Scheme (ILS), replicated from Gramen bank approaches. Yayasan Usaha Maju was established in June 1995 as a corporate entity. Moreover, KKR or People's Co-operative Credit is a co-operative credit scheme operating under the umbrella of the Credit Union, registered under the Society's Act.

Since Malaysia's declaring itself as the hub of Islamic financial services as well as Islamic economic training and education in the world, the innovation of financial products and Islamic fiscal-tools managed by a government are being prioritized, including Islamic micro-financing services. Like any other Moslem populatedcountries, the role of zakah, infaq and sadaqah and Islamic economic concepts are seemingly increasing, including in the process of structuring micro-financing products, whereby its sources are partially taken from the Islamic mechanisms mentioned above. Of course, the existing microfinance products have been modified into Islamic financial products, which comply with Sharia. The function of zakah, infaq and sadaqah actually is not only to bridge and narrow the gap between the rich and the poor in Islam by distributing directly, but also they can possibly be used to recreate funding sources for micro-financing, especially for the poor who are slightly above the poverty line, being able to fulfill minimum basic needs (Siwar \& Basri, 2001).

The massive project in acquiring land for farmers by initiating the effective projects called Crédito Fundiário in 2001 also involved a micro-financing scheme for farmers, whereby the farmers are beneficiaries. Beneficiary community associations along with heavy collaboration implemented it by local, state, and national civil society organizations. One of the local organizations involved was the National Confederation of Agricultural Workers (CONTAG), representing close to 4,000 unions with a membership of nearly 20 million rural workers in all States of Brazil. 
Its total project cost is $€ 340$ million, of which the World Bank finances 50\% (for investment subprojects and technical assistance), and the rest is financed by the Brazilian Federal Government (for land acquisition) and beneficiary contributions (which is approximately $10 \%$ of on farm investments). By December 2007, the Project had financed/contracted 2,366 land acquisition proposals benefiting 44,522 families on approximately 835,000 hectares of land (Blake, et.al, 2008).

The breakthrough of poverty alleviation programs in Bolivia began with reforming the law which allows the poor to access microcredit easily. Since the law has been rectified, the positive side of microcredit not only has brought about broader access and opportunities for the poor, but also provided choices, because microcredit has been a very promising and profitable business. Thus, as the underpinning regulation is changed, the providers of microcredit increase significantly. The Bolivian government is now in collaboration with not only the Inter American Development Bank and commercial banks, but also many regulated and legal nongovernmental organizations (NGOs) that are heavily involved, albeit having limitations in funding sources and operations. As a result of these collaborations, the microcredit funds and institutions in Bolivia have scaled up drastically.

For instance, one microcredit institution in Bolivia, the Bolivian BancoSol, upgraded from microcredit NGO, "in less than a decade, BancoSol nearly doubled its client base (reaching 121,207 borrowers in 2007 compared to 76,216 in 1997), and more than quadrupled its loan portfolio ( $\$ 209$ million in 2007, up from $\$ 48$ million in 1996)". Its negative side unfortunately must also be borne by the poor, since the microcredit institutions are rapidly privatized; the poor become the commodity of microcredit products and services, which seem to be profitable and promising businesses of financial channeling. Hence, the motive behind why many parties are voluntarily involved is no longer to assist the poor, but to gain profit. Basically, the negative side of privatized-microfinance institutions for the poor in Bolivia might begin with high interest rates, to attract more investment portfolios from institutional investors, the microcredit institutions however, are allowed to charge a higher interest up to $21 \%$, compared with normal loans of which are around $11.5 \%$.

The Venezuelan government has realized that an oil based-economy would not be strong enough and sustainable for its people and particularly in undertaking poverty alleviation programs, because most of its projects are based on direct subsidies without having socio-economic consequences in the long term nationally. Since 1989 the Venezuelan government has reformed its fiscal policy and national poverty strategy, moving from generalized subsidies funded by oil rents into productive activities facilitating fundamental exchange, trade and financial transactions. Thus through such initiatives greater job creation might be possible. Similar to Brazil, in 
Venezuela one of the most revolutionary policies in poverty alleviation is involving the poor in the tourism industry. This initiative does not require a very high level of training or education. Some jobs in the tourism sector are simpler than those in the manufacturing industry, but higher in value added. Regrettably, its developments also create the new drawbacks for Afro-American minorities instead of benefiting them.

\section{Conclusion}

Deliberating the topic of poverty must begin with the three terminologies: definition, profile and roots. World Bank defined poverty by quantifying the income of people with respect to their basic needs. People who earn an income or salary bellow 2 USD/day, according to World Bank's definition are considered as poor, and this definition prevails as the standard measurement worldwide. Like many other developing countries, the profiles of poor people living in both groups of countries highlighted in this research are of the ones who live in rural areas working as landless farmers and smallholder farmers, or the ones who is live in suburban slums surrounding the major cities working in informal sectors, moving from rural into urban areas, hoping for better jobs (Esman, 1978). The root of poverty problems is universal, no matter in which countries the poor are living in. First, "the poor" are being marginalized in the process of development, such that they are unable to participate and contribute significantly in the national economy; so far this has been among the most dominant cases. Second, systems of injustice are inherited from colonial masters and are still maintained by small groups of ruling-elites within countries generating economic benefit for themselves through modern slavery and legalizing minimum wages that are too low.

Through analysis of the statistical data and official reports released by reliable sources, the effort and programs fighting and addressing poverty both in Moslem and non-Moslem populated countries has resulted in better outcomes. However, Moslem populated countries in Asia have successfully narrowed the inequality gap between the poor and the rich, compared to non-Moslem populated countries in Latin America, in which the growth process tends to create an unequal distribution of income among their citizens. The policy and strategy comparisons in addressing poverty issues between Moslem populated countries and non-Moslem populated countries result in the common conclusions of similarities and differences. The general policies and strategies in the context of poverty alleviation between two groups of countries involve governments playing big roles and political willingness to do things like prioritize national budgets, allocation of funds to social expenditures in assisting the poor, such as direct food subsidies, healthcare packages, house subsidies, land distribution and so on. In both particular groups of countries, microcredit and micro financing have emerged as the common strategic solution of poverty alleviation, especially to help 
the poor who are starting new small businesses or improving and strengthening their existing business. In contrast, the most distinctive points between the two groups of countries are the involvement of religious teachings in poverty alleviation massively and the alternative strategic options. Obviously, in Moslem populated countries, the zakah, infaq and sadaqah play some roles in poverty alleviation and support the government programs. In non-Moslem populated countries, there are a few roles of religious practices in regards to social philanthropy supporting poverty alleviation, but their governments have proposed very significant changes and a more creative way out, such as the agenda of land reforms and developing a wider tourism industry.

\section{Limitation of the study and suggestion for future research}

There are some limitations of this research needed to be highlighted. In order to prove the significant role of each poverty alleviation tool, this research should be continued by quantitative research method. Therefore, it will be appropriate to measure the effectiveness of Moslem and Non Moslem populated countries' policies in eradicating their poverty.

\section{References}

Adnan, M. A., \& S.R. Ajija. (2015). The effectiveness of Baitul Maal wat Tamwil in reducing poverty: The case of Indonesian Islamic Microfinance Institution. Humanomics. Vol. 31 (2): 160 - 182.

Ahmed, H. (2004). Role of Zakat and Awqaf in Poverty Alleviation. Jeddah: Islamic Research and Training Institute.

Bardhan, P. (1984). Land, Labor, and Rural Poverty: Essays in Development Economics. New York: Columbia University Press.

Bautista, R. M. (1992). Development Policy in East Asia: Economic Growth and Poverty Alleviation. Pasir Panjang, Singapore: Institute of Southeast Asian Studies.

Blake, A. et.al. (2008). Tourism and Poverty Alleviation in Brazil. Retrieved August 15, 2016, from http://tradeinservices.mofcom.gov.cn/upload/2008/08/12/ 1218507256266_771980.pdf

Childress, M. D., \& Murnoz, J. A. (2008). Brazil Land-Based Poverty Alleviation

Project. Retrieved October 3, 2016, from http://siteresources.worldbank.org/

INTARD/Resources/Note31_Bazil_Poverty_web.pdf

Chyper, M. J. \& J.L. Dietz. (2009). The Process of Economic Development. New York, USA: Routledge Tylor and Francis Group.

Dorosh, P. et.al. (2004). The 1998 Flood and beyond: Towards Comprehensive Food Security in Bangladesh. Dhaka: University Press Limited. 
Eckholm, E. (1979). The Dispossessed of the Earth: Land Reform and Sustainable Development. Washington DC: Worldwatch Institute.

Esman, M. J. (1978). Landlessness and Near-Landlessness in Developing Countries. New York: Cornell University Press.

Filho, N. M. \& L. Vasconcellos. (2004). Has Economic Growth Been Pro-Poor in Brazil? Why? Retrieved October 7, 2016, from www.worldbank.org

Hofer, T. \& B. Messerli. (2006). Floods in Bangladesh. History, Dynamics and Rethinking the Role of the Himalayas. Tokyo: United Nations University.

Huq, S. (1998). NGOs Advocacy against The Structure Approach to Flood Control: The Case of the FAP in Bangladesh. A Journal of Policy Studies. Vol. 1 (2): 82-83.

Hutton, D. \& C.E. Haque. (2004). Human Vulnerability, Dislocation and Resettlement: Adaptation Processes of River-Bank Erosion-Induced Displaces in Bangladesh. Disasters. Vol. 28 (1): 41-62.

Jones, S., \& N. Nelson. (1999). Urban Poverty in Africa: From Understanding to Alleviation. London: ITDG Publishing.

Khan, M. H. (1986). Landlessness and Rural Poverty in Underdeveloped Countries. Pakistan Development Review. Vol. 2: 371-394.

Khan, M.H. (2000a). Rural Poverty in Developing Countries. Finance and Development. Vol. 37 (4): 26-29.

Khan, M.H. (2001). Rural Poverty in Developing Countries: Implications for Public Policy. International Monetary Fund Economic. Vol. 21: 1-13.

Khan, S. I. (2000b). Gram Bangla Model for Poverty Alleviation and Self-reliance. International Journal of Social Economics. Vol. 27: 878-892.

Kholid, M. et.al. (2009). Waqf Management through Sukuk Al Intifa'a: A Generic Model. Retrieved October 7, 2016, from https://www.islamicbanker.com/ publications/waqf-through-sukuk-al-intifa

McCarthy, J. J. et.al. (2001). Climate Change 2001: Impacts, Adaptation, and. Cambridge: Cambridge University Press.

Obaidullah, M. (2008). Role of Microfinance in Poverty Alleviation: Lessons from Experiences in Selected IDB Members Countries. Jeddah: Islamic Research and Training Institute.

OECD. (2016). OECD Income Distribution Database (IDD): Gini, poverty, income, Methods and Concepts. Retrieved October 27, 2016, from http://www.oecd. org/social/income-distribution-database.htm

Otsuka, K. \& Y. Hayami. (1988). Theories of Shared Tenancy: A Critical Survey. Economic Development and Cultural Change. Vol. 37 (1): 31-68. 
Quang-Dao, M. (2004). Rural Poverty in Developing Countries: An Empirical Analysis. Journal of Economic Studies. Vol. 31 (6): 500-508.

Rahman, A. R. (2010). Islamic Microfinance: An Ethical Alternative to Poverty Alleviation. Humanomics. Vol. 26 (4): 284-295.

Sadeq, M. \& A. Hasan. (1997). Poverty Alleviation: An Islamic Perspective. Humanomics. Vol. 13 (3): 110 - 134.

Salih, T. \& D. Colyer. (2000). A Case Study of Structural Transformations, Trade, and Poverty in Malaysia's Socioeconomic Development: 1960-1995. International Journal of Commerce and Management. Vol. 10 (1): 24-47.

Sánchez, M. \& M. Franklin. (1996). Poverty Alleviation Program for Minority Communities in Latin America. Washington, D.C.: Inter-American Development Bank.

Sapir, D. G. et.al. (2004). Thirty Years of Natural Disasters 1974-2003: The Numbers. Louvain: Presses Universitaires de Louvain.

Shillabeer, M. G. (2008). Poverty Alleviation or Poverty Traps? Microcredits and Vulnerability in Bangladesh. Disaster Prevention and Management. Vol. 17 (3): 396-409.

Siwar, C., \& A.T. Basri. (2001). Micro-Finance Capacity Assessment for Poverty Alleviation: Outreach, Viability and Sustainability. Humanomics, Vol. 17 (1): 116-133.

Tambunan, T. (1998). Poverty Alleviation, Participation of Females and Empowerment of People in Indonesia: Country Study. Humanomics. Vol. 4 (3): 76 - 106.

Todaro, M. P. \& S.C. Smith. (2006). Economic Development: Ninth Edition. New York: Pearson.

Ullah, A. A. \& J.K. Routray. (2007). The Rural Poverty Alleviation through NGO Interventions in Bangladesh: How Far is the Achievement? International Journal of Social Economics. Vol. 34 (4): 237-248.

UNDP. (2002). Human Development Report. New York: United Nations Development Program.

Whitman, S. (2008). World Poverty. New York: Fact on File, Inc.

World Bank. (1993). Handbook of Poverty Reduction. Washington D.C: World Bank.

World Bank. (2015). World Bank Open Data. Retrieved October 23, 2016, from http://data.worldbank.org/

World Bank. (2011). World Development IndicatorsWorld Development Indicators. Retrieved October 10, 2016, from www.worldbank.org

Wratten, E. (1995). Conceptualizing Urban poverty in Environment and Urbanization. Environment and Urbanization. Vol. 7 (1): 11-38 . 